
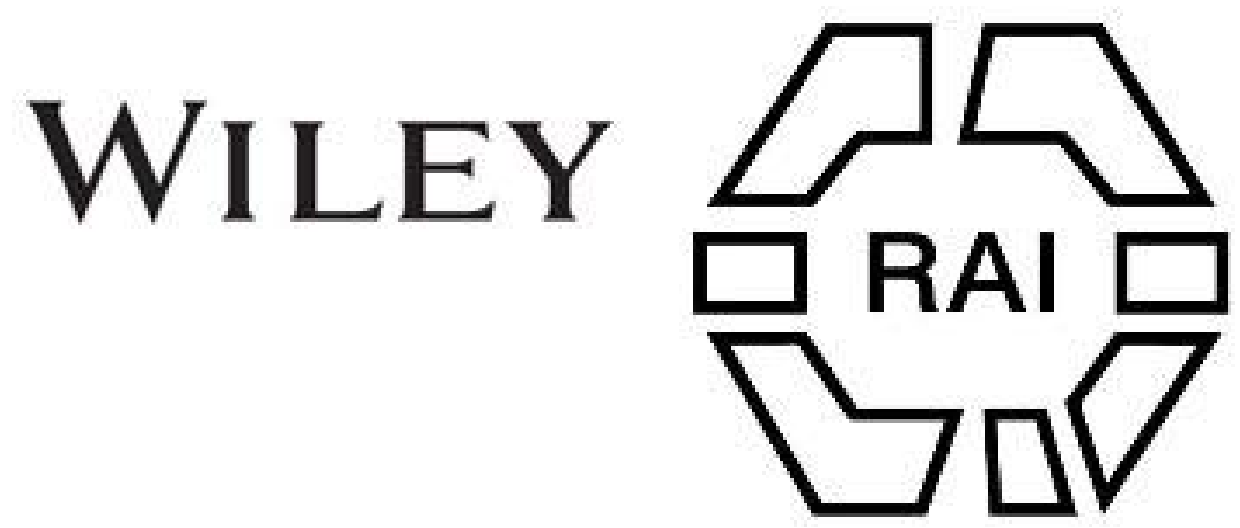

\title{
5. The Aruac Indians of Venezuela.
}

\section{Author(s): A. C. Breton}

Source: Man, Vol. 21 (Jan., 1921), pp. 9-12

Published by: Royal Anthropological Institute of Great Britain and Ireland

Stable URL: http://www.jstor.org/stable/2840646

Accessed: 25-06-2016 07:10 UTC

Your use of the JSTOR archive indicates your acceptance of the Terms \& Conditions of Use, available at

http://about.jstor.org/terms

JSTOR is a not-for-profit service that helps scholars, researchers, and students discover, use, and build upon a wide range of content in a trusted digital archive. We use information technology and tools to increase productivity and facilitate new forms of scholarship. For more information about JSTOR, please contact support@jstor.org.

Wiley, Royal Anthropological Institute of Great Britain and Ireland are collaborating with JSTOR to digitize, preserve and extend access to Man 
There are some languages, "Mixed S.B.," which have both Sudanic and Bantu elements and are very puzzling when it comes to a question of classification. There are others, forming a Sudanic sub-group, which have prefixes resembling Bantu (in Nigeria such prefixes are, according to Dr. Struck, mainly those of E. and S. Bantu languages) and concord of the verb up to a certain point. These prefixes differ, as a matter of course, from those of the mixed S.B. languages, which are allied to the north-west Bantu forms.

In connection with classification I may mention the case of Yala, dealt with by Sir H. H. Johnston as a semi-Bantu speech. In my Specimens (1914) I classed this with Edo on the ground of partial identities of vocabulary; we find, e.g., Yala, ikpiri, eye, Wefa, ukpelo; Y. ikboto, heart, W. ukbo; Y. esi, ib' isi, back, W. itsike; Y. abo, hand, W. obo ; Y. oku, blacksmith ; Edo, og $\tilde{n} ;$ Y.igwo, ten, E. igbe, Y. igwole, eleven, E. iworo. Other Yala words correspond more closely to Ibo ; Y. ipfo, belly, I. afo; Y. oinya, woman, I. nwunye (dial. pl. inyime), Y. onye (man), he who, found in Kedea also ; Y. oiya, friend, I. oiyi. These examples could easily be multiplied.

So far as vocabulary is concerned, it seems that Yala has West Sudanese affinities in perhaps half its vocabulary. If that is so, strong evidence is needed before it can be classed as semi-Bantu in the restricted sense. If under semi-Bantu are included both Sudanic tongues influenced by Bantu, Sudanic tongues influenced by semi-Bantu, Bantu tongues degraded by association with non-prefix languages, and semi-Bantu proper, that must be of ancient origin, the advantage of this grouping is not obvious, at any rate a good deal of subdivision is necessary.

N. W. THOMAS.

Venezuela: Ethnography.

Breton.

The Aruac Indians of Venezuela. By A. C. Breton.

A volume* of old Spanish manuscripts relating to America, from Lord Kingsborough's collection and belonging to the British Museum, contains a document with description of the Lake of Maracaybo in Venezuela and its Indians, written between 1573 and 1575. This has two maps and many coloured illustrations with notes on the animals and useful plants, also small drawings of native houses and weapons (Fig. 1). Early notices of the people are valuable and the following is a literal translation of the pages concerning them.

The Indians of the lake and its shores are in rery great numbers, barbarous, not domesticated nor in charge of encomenderos. They have their huts and dwellings in the water of the lake with towns of thirty or more houses in each, raised on bridges and palisades of thick and strong beams which they call barbacoas. Here they do their business and on the mainland they have their fields and cattle. They have canoes made of a single tree, without nails, as will be described later.

These Indians are poor, light chestnut in colour, with wide foreheads, no beard, thick black hair, and are of honest disposition and industrious. They go unclothed and are very sluggish with their fcet and movements. They are poor labourers, from being brought up on the lake and passing their lives there. Even mature men seldom leave it, and when they do it is to pass to the mainland to attend to their small farms and crops and the men who work reside in the lake most of the year. They are not farmers, nevertheless they have their fields of maize, yuca and other vegetables with profit, and also raise cattle. They are very maritime, energetic fishermen not warlike.

Their trade is in salt and fish, which they exchange with other Indians of the coast and inland regions, bartering them for certain gold ear ornaments, caracuries and other jewels of their

* Add. MSs. 13, 964.

$\left[\begin{array}{ll}9 & ]\end{array}\right.$ 
making. Their method of catching fish in the lake and rivers is with lines and hooks and with hafted harpoons, which they muke of tortoiseshell, and some of strong iron made by Spaniards and Indians of Venezuela. These harpoons they attach to lances and throw the harpoon at the fish To fish or for other work in the lake they go in canoes made of a single trunk, without any kind of nails. The largest is from twenty to twenty-two feet long, four palmas [hands] wide
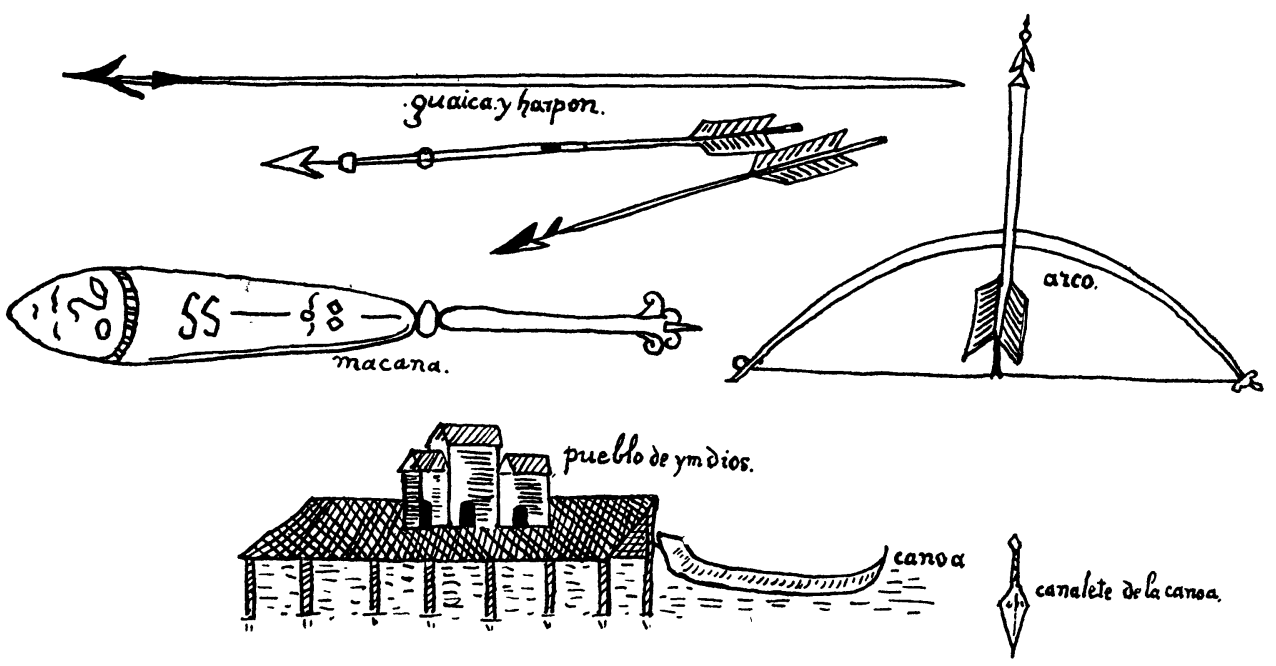

FIG. 1.

\author{
Native weapons and village, venezuela.
}

and three or more deep, and in these go men, women, and boys of 15 to 18 years or less, doing their jobs. When a man goes in the said canoe, to avoid having another to row, he manages to fish and row also, sitting on the prow or stern, with one leg in the water and the other in the canoe, steering and paddling with his foot with much ease, having his hands free to fish, etc. At other times they have paddles and rowers who use them with their arms.

'Their principal sustenance is fish, and much shell fish, especially crabs and xayjas; some deer meat barbecued, which they get with balls of maize, from the inland Indians by exchange; tortillas, salt, much chicha of maize, sweet potatoes and sweet yuca. They have great knowledge of the seasons of the year, ruled by the moons, which are their reckonings of times and months. As we say one, two, three months, they say $1,2,3,4$ moons and so on up to the required number. They take much pleasure in their dances and drinking feasts, to which they invite each other. These always begin at dusk and last till dawn, with musical instruments and singing, making a pleasant measured sound, with chorus, and dances of different kinds, some entering and others going out in turn, with many varieties of steps, leaps and movements of the body. The performers are painted red and have feather ornaments. In these and other feasts they observe the decorum of the chiefs and principal men, who are distinguished by their seats and insignia. At last, all are intoxicated with the chicha they drink, which has the effect of wine, so that the more they drink the more intoxicated they become. In these festivals they do nothing but drink and in them they bring to memory their pleasures, labours and deaths, both past and present.

They usually have two or more wives and require them to be faithful, treating them honestly in their fashion. They like to be esteemed, regaled and well treated. By doing this and not carrying off their wives and daughters, they would be easily won over to Spanish government.

Their arms, offensive and inoffensive, are guaycas, also called dardos (darts or harpoons) of one or two points, and these toasted to harden them, of a black and tawny wood, with feathers; bows of the same wood and many sharp arrows with one head but with many points of divers kinds. In the drawing and use of these bows they are very quick and alert. When they go from the lake to the mainland, in the meadows going to their crops, with the said buws and arrows (which they always carry) they kill deer and Spanish rabbits as they flee before them, and the same in the sea and rivers, so that at two fathoms' depth they kill many kinds of fish with great ease and artifice. 
They use little of the poison herb, and it does not produce rabies* though mortal in effect. Another weapon is the macana, $\dagger$ made of the same wood as the bows. They use it like a broadsword with both hands and over the head with great swiftness of the arms, the feet quiet, with loud cries and noise of flutes and drums. This is a terrible weapon, incurable in its blows, for wherever it strikes it breaks and bruises.

The river Espiritu Santo flows into the lake and its shores are inhabited by native Indians. Vessels of shallow draught can go up this river tewards the new kingdom of Granada with all kinds of merchandize, and by forming ports whence droves of mules could proceed, the deaths and ill-treatment of Indian carriers would come to an end.

Inland from the lake, the country is rich in gold, which could be mined, and the land is good for wheat and cattle raising, with great numbers of Indians, not domesticated nor given to encomenderos. They have towns of 40 to 200 huts together and some apart. They have caciques, whom they obey, and the chieftainship descends to the nearest relative. They are good cultivators, of excellent disposition; light chestnut colour, round-faced, witbout beards, hair very black and thick, not valiant nor inclined for war. They are of better quality and condition than those of the iake, more generous, much better walkers, workers and labourers. They like to be treater honestly and do that themselves; are very jealous. They usually have two or more wives, understand their own interests, and if their wives and daughters are not taken from them they can be easily managed and drawn to the king's service. They are rich in their way. Most of them, especially the women and children, wear gold ornaments, of which they have many of 20 carats or less, worked into caracuries, chagrualas, ear-ornaments, eagles, frogs and chaquiras, which they get from other Indians who live near them.

They go unclothed, although their chief and best trade is spinning cotton cloths, both fine and thick, and hammocks. After spinning, they weave as we do. These cloths are the thin and good kind used by the Spaniards, equal to very good "Ruan" [linen of Rouen]. They barter these cloths with Indians of the interior for gold from the new kingdom of Granada.

They recognize and obey their chiefs and elders: have very great knowledge of the seasons and reckon by moons for their crops like those of the lake. Their chief,food is fish, which they kill in the rivers, and also go down to exchange that of the lake Indians for gol $\gamma$, deer meat, small native pig barbecued, rabbits, balls and tortillas of maize, much chicha made from it, yucaduse and potatoes.

The account of the dances and drinking feasts at night, is in the same words as that of the lake, except that the inland folk were much better arranged. Their arms were the same, but they were more expert and wonderful with the macana. On the second map are many written notes on the great number of Indians inhabiting the coast regions from the Orinoco (called Rio del Drago) westward. "By this " river come Indians from more than 300 leagues in their canoes to barter trumpets, " pearls, salt and axes with those of Trinidad and even with colonists of the island " of Margarita, which they reach in their canoes under care of other Aruac Indians " who are of the coast more to windward of Trinidad. They have much gold, and " are certainly Guayaneles of the Dorado."

At that time the principal mouth of the Orinoco appears to have been in the gulf of Paria, and its fresh water was carried more than 11 leagues out to sea. 'The map extends from the Orinoco to the Magdalena river, and contains the Spanish towns founded up to 1570. Coro was the original Venezuela or little Venice, called so from the native pile-dwellings. East of the Orinoco the people were rich and clothed. On another page the sites are given of twenty-five Indian villages round the lake of Maracaybo, which has much silted up in the intervening 350 years, so

* Is the Indian constitution especially liable to rabies? In south-west Mexico the bite lof the deadly grey scorpion affects men in that way, whilst an American or English person only suffers temporary paralysis and other unpleasant symptoms. The Caribs of Trinidad in 1534 used a poison for their arrows which "caused the wounded to die in paroxysms of fury, tearing pieces out of their flesh."

$\dagger$ The macana figured differs from modern ones of the same region. Specimens of the latter are in the Pitt Rivers Museum at Oxford and at Exeter. The one described was doubtless made of an exceptionally hard and heavy wood. The term macana was general from Mexico to Peru, due, perhaps, to the Spaniards' use of the Mexican name, as of other nouns, such as tecomate (a dish made from a gourd) still used in Mexico and Peru.

$\left[\begin{array}{ll}11 & ]\end{array}\right.$ 
that there will be a rich harvest for the archæologist of the future. The island of Trinidad was uninhabited from 1571 to 1575 , and the writer of the document advises that it should be re-colonized speedilv " to stop the landing of corsairs there and the risks from the Drago [Drake] and other notable ones."

Evidently the Spaniards had killed off the natives they met and the number who had settled again round the lake of Maracaybo did so when their invaders retreated owing to the resistance offered by the Caribs. Judging from modern photographs of Caribs and Aruacs, ${ }^{*}$ there could not be much racial difference between them, and they are similar in features to the people of the Mexican State of Vera Cruz. The Caribs had become fierce through their practice of exogamy and need of fighting to obtain wives from other tribes.

The object of the document quoted from was to obtain a grant in perpetuity of the land round the lake of Maracaybo. Several pages are filled with the terms and conditions proposed, including perpetual enslavement of the whole native population. The document is signed Diego Sanchez de Sotomayor.

A. C. BRETON.

Ireland: Archæology.

\section{REVIEWS.}

National Museum of Science and Art, Dublin. Guide to the Collection of Irish Antiquities. Catalogue of Irish Gold Ornaments in the Collection of the Royal Irish Academy. By E. C. R. Armstrong, F.S.A., Keeper of Irish Antiquities. Pp. iv +104 . Pl. xix. Dublin : Stationery Office, 1920. Price 2s. net.

Mr. Armstrong has done a great service to archæologists in issuing this admirable catalogue, which is also a most complete monograph on the subject of the gold of prehistoric Ireland, and the trade between that island and France, Germany, and Scandinavia ; the footnotes form a bibliography of this interesting subject. A short description is given of each object as well as an illustration on half-scale. It is, perhaps, unfortunate that, owing to the high cost of printing and paper, it has been necessary somewhat to crowd the plates and to make some of the illustrations overlap; this, however, does not detract from the scientific value of the volume.

If one may offer a criticism on so admirable a production, it is that the term fibula, first used in this connection by Wilde, does not seem applicable to the crescent-shaped penannular rings terminating in flat or cup-shaped dises. It would seem more appropriate to confine this term to brooches with pins attached. It only remains for us to hope that some day Mr. Armstrong will give us equally wellillustrated catalogues of the copper and bronze objects under his charge.

\section{New Guinea: Ethnography.}

H. J. E. P.

Unexplored New Guinea. By W. N. Beaver, with an introduction by A. C. Haddon, M.A., Sc.D., F.R.S. London : Seeley, Service \& Co., Ltd., 1920.

This is the first attempt, we believe, to gather together into the compass of a single volume an account of the country and natives of the whole of the Western Division of British New Guinea, a district which has received somewhat scant notice in the past. The author has drawn his information not only from previous works, but also largely from his own experiences during a residence of ten years in the country, the greater part of the time as a Resident Magistrate. Thus he has been able, besides checking and coufirming previous accounts, to contribute a good deal of original material. He calls the book a record of travel and adventure, but it is much more than that. Elhnology, in fact, occupies the greater part of the

* Dr. W. Farabee's Amazon expedition. A Spanish gazetteer of 1600 gives the province of the Aruacas to the south of Trinidad (delta of the Orinoco), and that at that date they were still unconquered. Hakluyt's map of about the same time calls it the Caribs' province.

$$
\text { [ } 12]
$$

